\title{
Spatial variation in the trophic base of the trichopteran filter feeder Stenopsyche marmorata in an intermittent river in Japan
}

\author{
Hyun-Seon Shin*, Osamu Mitamura \\ Limnology Laboratory, Environmental Science Graduate School, University of Shiga Prefecture, Hikone 522-0057, Japan
}

\begin{abstract}
Carbon and nitrogen stable isotope analyses were used to determine how a trichopteran filter feeder Stenopsyche marmorata Navas (Stenopsychidae) reflects shifts in food sources (suspended particulate organic matter [SPOM], benthic particulate organic matter [BPOM], and periphyton) in response to channel drying in the alluvial soils of the Inukami River in Japan. The $\delta^{13} \mathrm{C}$ and $\delta^{15} \mathrm{~N}$ values of consumers shifted to a pattern similar to that of BPOM in an intermittent river, which suggests that particulate organic matter at each station may play an important role as a food source. Moreover, analysis of the upper reaches of the dry channel revealed that both consumers and food sources have enriched $\delta^{13} \mathrm{C}$ values due to physicochemical characteristics in the channel such as a high water temperatures and stagnant water. Conversely, the lower reaches showed more negative $\delta^{13} \mathrm{C}$ values, suggesting either a lack of carbon or a reduced supply of terrestrial dissolved carbon, both caused by channel drying, and higher $\delta^{15} \mathrm{~N}$ values, suggesting a high dissolved inorganic nitrogen concentration in groundwater. Our study showed that a dry channel may influence the flow of energy between consumers and their food sources and the flow of nutrients from the upper to the lower reaches.
\end{abstract}

KEY WORDS: Trichopteran filter feeder $\cdot \delta^{13} \mathrm{C} \cdot \delta^{15} \mathrm{~N} \cdot$ Channel desiccation $\cdot$ Inukami River Resale or republication not permitted without written consent of the publisher

\section{INTRODUCTION}

River ecosystem food webs depend on 2 main energy sources, those derived from primary producers within the river (autochthonous) and those derived from terrestrial organic sources originating from terrestrial plant matter (allochthonous). These 2 main energy sources have qualitative differences (Thorp \& Delong 2002) and react differently to environmental changes (Hungate \& Marks 2002). Moreover, the supply of allochthonous sources is usually higher than autochthonous primary production in the majority of rivers (Cole \& Caraco 2001, Caraco \& Cole 2004). However, recent studies of intermittent river systems showed conflicting results regarding the relationship between allochthonous (Reid et al. 2008, Dekar et al. 2009) and autochthonous (Bunn et al. 2003) production as main food sources.
In general, intermittent streams dry up during certain times of the year and are often located above local groundwater tables (Wigington et al. 2006). Groundwater discharge from perched aquifers may still be the primary source of annual stream flow in intermittent streams (Rains et al. 2006). During the drying process, the biota of intermittent streams must tolerate various physicochemical and biological limitations (Williams 1996), such as decreasing habitat and increasing ionic concentration and $\mathrm{pH}$ (Arab et al. 2004). Arab et al. (2004) reported that the macroinvertebrate community in an intermittent river contained few species and that Chironomidae was the dominant taxon. However, Iwadate et al. (2007) demonstrated that trichopteran filter feeders (such as Stenopsyche marmorata) represented the highest percentage of total aquatic insects in intermittent water. Similarly, in the Inukami River, S. marmorata was the predominant 
macroinvertebrate (Shin et al. unpubl. data), with a high biomass.

In the present study, we conducted stable isotope analyses using Stenopsyche marmorata and its food sources (suspended particulate organic matter [SPOM], benthic particulate organic matter [BPOM], and periphyton) to examine responses to channel drying in the upper and lower reaches of the Inukami River. In general, stable isotope ratios of consumers directly reflect only those food sources that are incorporated into body tissues over extended periods of time (Rounick et al. 1982, Finlay 2001). The objectives of our study were to identify the trophic pathways of $S$. marmorata from its food sources based on physicochemical characteristics associated with a dry river channel. We evaluated shifts in consumer trophic bases and basal resources at each station using carbon and nitrogen stable isotope analysis.

\section{MATERIALS AND METHODS}

Study locale. The present study was conducted in the Inukami River $\left(35^{\circ} 0^{\prime} \mathrm{N}, 136^{\circ} 0^{\prime} \mathrm{E}\right)$ in the northeastern region of Shiga Prefecture; Japan. The Inukami River is $27 \mathrm{~km}$ long, has a catchment area of approximately 105 $\mathrm{km}^{2}$, and flows into the eastern Lake Biwa region of Japan (Fig. 1). Mean annual precipitation in this watershed is $1571 \mathrm{~mm}$ (Hikone Regional Meteorological Office). During the dry season (August and November to December), the Inukami River has a dry channel approximately 4 to $9 \mathrm{~km}$ from the river's mouth (Fig. 2).

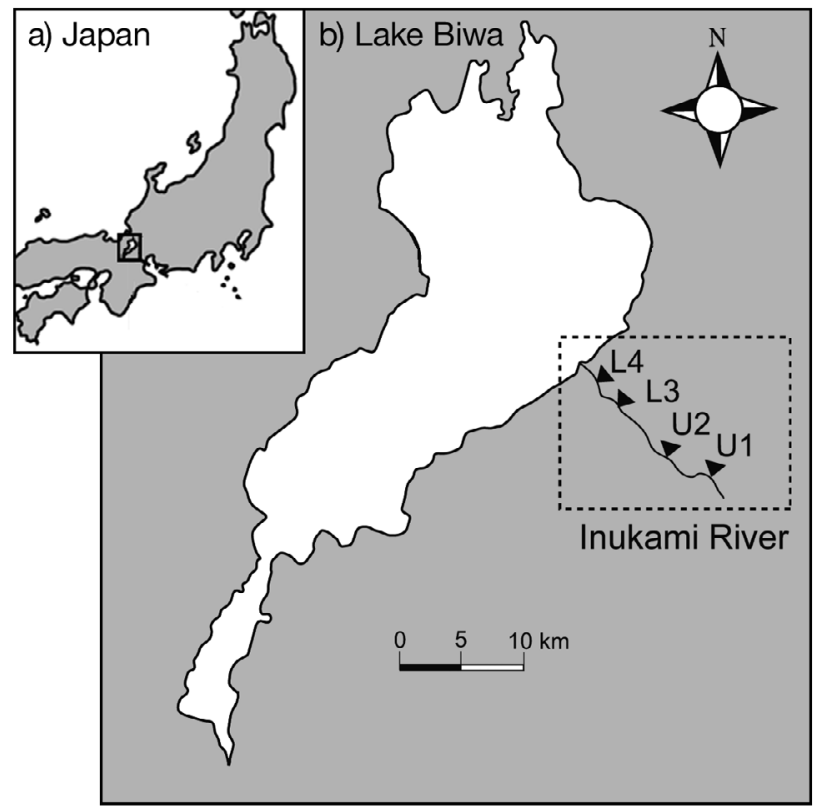

Fig. 1. (a) Location of the study area in Japan. (b) Location of the study stations along the Inukami River
We established 2 stations (U1 [35 ${ }^{\circ} 11^{\prime} 19.4^{\prime \prime} \mathrm{N}, 136^{\circ} 18^{\prime}$ 58.7" E] and U2 [35 $\left.12^{\prime} 26.5^{\prime \prime} \mathrm{N}, 136^{\circ} 16^{\prime} 40.7^{\prime \prime} \mathrm{E}\right]$ ) in the area above the dry channel ('upper reaches') and 2 stations (L3 (35 $\left.14^{\prime} 31.4^{\prime \prime} \mathrm{N}, 136^{\circ} 14^{\prime} 0.6^{\prime \prime} \mathrm{E}\right)$ and L4 ( $\left.35^{\circ} 15^{\prime} 23.4^{\prime \prime} \mathrm{N}, 136^{\circ} 13^{\prime} 39.1^{\prime \prime} \mathrm{E}\right)$ in the area below the dry channel ('lower reaches'). U1 was located in the headwaters, U2 was located at a subflow area, and L3 and L4 were located in a spring area (Fig. 2).

Sample collection and preparation. Benthic macroinvertebrates were collected at the 4 stations in August 2008. We conducted sampling with 3 replicates using a square Surber sampler $\left(250 \mu \mathrm{m}\right.$ mesh; $0.25 \mathrm{~m}^{2}$ sampling area). All biota were separated from the other material and sorted in the laboratory. Aquatic insects collected at the sampling stations were identified predominantly under a stereoscopic microscope, and only Stenopsyche marmorata were selected for use in the experiments.

Physicochemical parameter analyses. Current velocity was measured at the study stations using a digital current meter (Model-3631, Yokogawa) at $1 \mathrm{~m}$ intervals from the right to the left bank. Water temperature (WT) and electrical conductivity (EC) were measured using a multiple water-quality sensor (U-22, Horiba), and $\mathrm{pH}$ was measured by colorimetry. Dissolved oxygen (DO) concentration was determined using the method described by Winkler (1888). To determine major cation $\left(\mathrm{Na}^{+}, \mathrm{K}^{+}, \mathrm{Mg}^{2+}\right.$, and $\left.\mathrm{Ca}^{2+}\right)$ and anion $\left(\mathrm{Cl}^{-}\right.$and $\left.\mathrm{SO}_{4}{ }^{2-}\right)$ concentrations, water samples were filtered through filter paper (Toyo No. 5C; $1.0 \mu \mathrm{m}$ pore size, $24 \mathrm{~mm}$ diameter) and stored in a refrigerator. Major ionic elements and nitrate concentrations were analyzed using an ion chromatographic analyzer (Dionex DX-120). Water samples for nutrient and dissolved organic carbon (DOC) con-

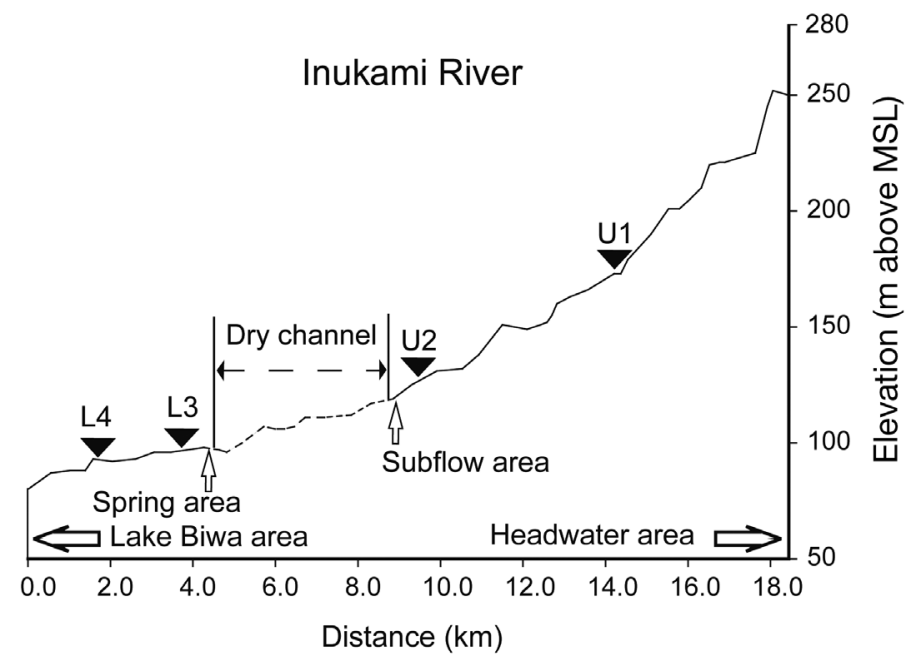

Fig. 2. Longitudinal section of the Inukami River, including Stations U1 and U2 in the upper reaches and L3 and L4 in the lower reaches of the river. MSL: mean sea level 
centration analyses were filtered through a glass-fiber filter (Whatman GF/F; $0.7 \mu \mathrm{m}$ pore size, $24 \mathrm{~mm}$ diameter) after combustion at $420^{\circ} \mathrm{C}$ for $3 \mathrm{~h}$. Ammonium concentration was determined using the method reported by Sagi (1966); nitrite concentration, Bendschneider \& Robinson (1952); phosphate concentration, Murphy \& Riley (1962); and silicate concentration, Mullin \& Riley (1955). DOC concentration was measured by a high-temperature oxidation technique using a total organic carbon analyzer (Shimadzu Model 5000). We collected the algae attached to stones in a quadrat $(5 \times 5 \mathrm{~cm})$ by scouring the surface of stones with a brush and then measuring dry weight. We assumed that most of the algae collected consisted of periphyton, and we used these data later in the paper to represent periphyton. Chlorophyll a ( $\mathrm{chl} \mathrm{a}$ ) concentration was determined using a fluorometer (Turner Designs 10-AU). SPOM concentration was obtained by collecting $400 \mathrm{l}$ of river water using a bucket, filtering it through a glass-fiber filter (Whatman GF/F; $0.7 \mu \mathrm{m}$ pore size, $47 \mathrm{~mm}$ diameter) and then measuring dry weight.

Analytical procedures for measuring stable isotope ratios. Trichoptera Stenopsyche marmorata larvae and their potential food sources were collected at the respective stations. S. marmorata individuals were maintained in filtered river water at $5^{\circ} \mathrm{C}$ for $24 \mathrm{~h}$ to allow elimination of gut contents. Lipids were removed by extraction in chloroform and methanol (2:1), as described by Folch et al. (1957), to avoid variations in $\delta^{13} \mathrm{C}$ values because of species-dependent differences in the concentrations of isotopically lighter lipids (Focken \& Becker 1998). The samples were then freeze-dried until subsequent treatment.

We analyzed the stable isotopes of carbon and nitrogen in samples of SPOM, BPOM, and periphyton, the potential food sources for Stenopsyche marmorata. SPOM was collected by filtering the river water through GF/F glass-fiber filters (Whatman GF/F; $0.7 \mu \mathrm{m}$ pore size, $24 \mathrm{~mm}$ diameter), BPOM was collected from the streambed using sieves with $<250 \mu \mathrm{m}$ mesh sizes, and periphyton was collected by scouring surfaces of stones within a $5 \times 5 \mathrm{~cm}$ quadrat using a brush. SPOM, BPOM and periphyton samples were acidified with $1 \mathrm{~N} \mathrm{HCl}$ to remove carbonates. The samples were freeze-dried and stored in a freezer at $-20^{\circ} \mathrm{C}$ until the stable isotope ratios were analyzed.

BPOM is considered to be composed of 2 sources: periphytic algae and allochthonous sources (Vannote et al. 1980, Allan 1995). We calculated the contribution of each source to BPOM using a 2-source carbon isotope mixing model (Phillips \& Gregg 2001). We used the mean literature values of terrestrial leaf litter in the study stream $(-28.0 \%$; France 1995$)$ as the $\delta^{13} \mathrm{C}$ value of terrestrial sources. Based on the $\delta^{13} \mathrm{C}$ and $\delta^{15} \mathrm{~N}$ signatures, the relative importance of the food sources to the diets of Stenopsyche marmorata was estimated using IsoSource, the mixing model developed by Phillips \& Gregg (2003). For this calculation, we used a mean $\delta^{13} \mathrm{C}$ value of $0.8 \%$ and a mean $\delta^{15} \mathrm{~N}$ value of $3.4 \%$ in the isotopic fractionation (DeNiro \& Epstein 1978, Minagawa \& Wada 1984, Post 2002) between S. marmorata and its food sources. Stable isotope ratios of the samples were measured with an elemental analyzer (EA1108; Fisons) connected to a mass spectrometer (Delta S; Finnigan MAT) using an interface (Conflo II; Finnigan MAT) with 3 replicates.

The reported $\delta^{13} \mathrm{C}$ or $\delta^{15} \mathrm{~N}$ values are relative to carbon in Peedee belemnite (PDB) limestone and nitrogen in air, respectively, using the following equation:

$$
\delta^{13} \mathrm{C} \text { or } \delta^{15} \mathrm{~N}(\%)=\left[\left(R_{\text {sample }}-R_{\text {standard }}\right) / R_{\text {standard }}\right] \times 10^{3}
$$

where $R$ is ${ }^{13} \mathrm{C} /{ }^{12} \mathrm{C}$ or ${ }^{15} \mathrm{~N} /{ }^{14} \mathrm{~N}$. Analysis errors for $\delta^{13} \mathrm{C}$ and $\delta^{15} \mathrm{~N}$ were within $\pm 0.2 \%$. Data were analyzed using SigmaPlot v. 10.0 (Systat Software Inc).

To test for differences in Stenopsyche marmorata and its food sources at each station, analyses were performed using 1-way (factor) analysis of variance (ANOVA) and the Tukey multiple comparison (Tukey HSD) procedure. All statistical analyses were performed using SPSS v. 17.0.

\section{RESULTS}

\section{Physicochemical parameters}

General physicochemical parameters recorded at the sampling stations are shown in Table 1. At U2, water depth and discharge were the lowest and WT $\left(33.2^{\circ} \mathrm{C}\right)$ was the highest compared to other stations. $\mathrm{pH}$ values were higher at U1 and U2 (pH 8.2 and 8.4, respectively) than at L3 and L4 (pH 7.2 and 7.4). Some chemical characteristics such as chloride, sulfate, and sodium ion concentrations also showed significant differences between U1 and U2 and L3 and L4 ( $t$-test, all p < 0.05). Moreover, nitrate $(43.8 \mu \mathrm{M})$ and phosphate $(1.3 \mu \mathrm{M})$ concentrations at L3 and ammonium $(2.3 \mu \mathrm{M})$ concentration at U2 were higher compared with those at the other stations. The dissolved inorganic nitrogen (DIN; sum of nitrate, nitrite, and ammonium nitrogen) concentration was composed mainly of nitrate and increased between U2 (28.0 $\mu \mathrm{M})$ and L3 (45.3 $\mu \mathrm{M})$ (Fig. 3). In contrast, the DOC concentration decreased between U2 (1.5 $\mathrm{mg} \mathrm{l}^{-1}$ ) and L3 (0.9 $\mathrm{mg} \mathrm{l}^{-1}$ ) (Fig. 3). Similarly, SPOM volume decreased significantly between U2 $(0.32 \mathrm{mg}$ $\mathrm{l}^{-1}$ ) and the lower reaches (L3 and L4: 0.03 and $0.05 \mathrm{mg}$ $\mathrm{l}^{-1}$, respectively) (Fig. 4). Mean chl a concentration for periphyton appeared to be significantly different between $\mathrm{U} 1$ and $\mathrm{U} 2$ (56 and $77 \mathrm{mg} \mathrm{m}^{-2}$, respectively) and L3 and L4 (158 and $166 \mathrm{mg} \mathrm{m}^{-2}$ ) (Fig. 5). 


\begin{tabular}{|c|c|c|c|c|}
\hline 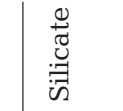 & 岁 & $\stackrel{\infty}{\stackrel{\infty}{-1}}$ & $\overrightarrow{\mathfrak{m}} \widehat{\mathcal{I}}$ & $\stackrel{\infty}{\rightarrow} \underset{-}{\sigma}$ \\
\hline $\begin{array}{ll}\dot{1} & 0 \\
0 & \frac{1}{\pi} \\
\frac{1}{1} & \frac{1}{2}\end{array}$ & 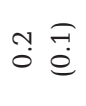 & $\stackrel{n}{0}$ & $\begin{array}{l}m \\
\stackrel{0}{0}\end{array}$ & $\begin{array}{ll}0 \\
0 & 0 \\
0 & 0\end{array}$ \\
\hline 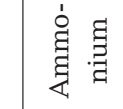 & $\begin{array}{ll}0 & 0 \\
0 & \dot{e}\end{array}$ & $\stackrel{m}{i}$ & 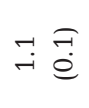 & $\stackrel{\overbrace{}}{\sim}$ \\
\hline 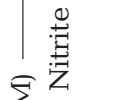 & \begin{tabular}{ll}
\multirow{0}{0}{} \\
0
\end{tabular} & $\stackrel{\sharp}{0}$ & $\begin{array}{l}\ddot{0} \\
\dot{0}\end{array}$ & $\begin{array}{ll}\text { N } & 0 \\
0 & 0\end{array}$ \\
\hline 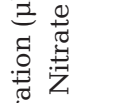 & $\begin{array}{l}\vec{F} \\
\dot{m} \stackrel{0}{=}\end{array}$ & $\stackrel{\sim}{\stackrel{\sim}{\sim}}$ & 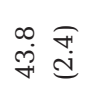 & 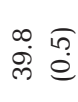 \\
\hline 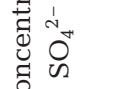 & 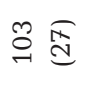 & $\vec{I}$ & $\stackrel{\Re}{N} \Xi$ & $\stackrel{\infty}{\vec{N}} \varrho$ \\
\hline$\dot{U}$ & $\stackrel{\circ}{\overparen{I}}$ & $\stackrel{0}{0}$ & $\stackrel{m}{\varpi} \Xi$ & ర్లి త్త \\
\hline$\stackrel{+}{\tilde{U}}$ & ? & 齐 & ชి తి & $\vec{\infty} \mathbb{0} \Phi$ \\
\hline$\stackrel{+}{\overbrace{}^{+}}$ & $\infty$ శ్ & ตั & $\stackrel{m}{0} \Xi$ & $\stackrel{g}{\ominus} \Xi$ \\
\hline بـ & $\stackrel{\sim}{\sim}$ & $\stackrel{2}{\sim}$ & $\stackrel{\mathcal{N}}{\Xi}$ & $\stackrel{\sim}{e}$ \\
\hline$\stackrel{+}{Z}_{Z}$ & $\stackrel{\leftrightarrow}{0} \stackrel{0}{=}$ & ๗ֶ. & $\underset{+}{\infty} \underset{+\infty}{\infty}$ & $\underset{+}{\infty} \mathbb{\infty}$ \\
\hline 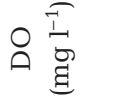 & $\begin{array}{l}\infty \\
\infty \\
\infty\end{array}$ & a & $\ddot{\infty}$ & 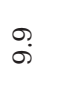 \\
\hline & $\underset{\infty}{\infty}$ & $\stackrel{+}{\infty}$ & $\stackrel{N}{N}$ & $\stackrel{4}{\sim}$ \\
\hline 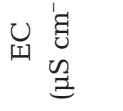 & $\begin{array}{l}\infty \\
\stackrel{\infty}{\sim} \\
\sim\end{array}$ & $\stackrel{\infty}{\infty} \underset{\infty}{\infty}$ & 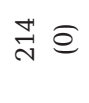 & $\stackrel{\leftrightarrow}{\stackrel{)}{~}}$ \\
\hline$\stackrel{50}{30}$ & $\overrightarrow{\ddot{N}} \stackrel{\mathbb{N}}{=}$ & 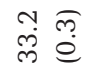 & $\begin{array}{l}0 \\
\ddot{j} \\
\dot{\theta}\end{array}$ & $\begin{array}{l}\circ \\
\stackrel{0}{\oplus} \\
\stackrel{0}{0}\end{array}$ \\
\hline 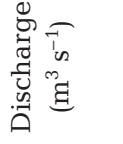 & $\stackrel{\oplus}{\sim}$ & $\stackrel{n}{\rightarrow}$ & 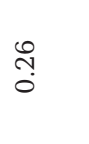 & ก̃ \\
\hline 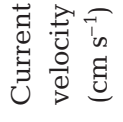 & 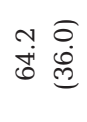 & 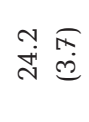 & $\begin{array}{ll}0 & \sigma \\
\dot{H} & 0 \\
\stackrel{\infty}{0}\end{array}$ & 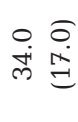 \\
\hline 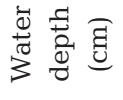 & $\begin{array}{l}\hat{\sigma} \\
\dot{\omega} \\
\dot{\omega}\end{array}$ & $\stackrel{\circ}{\stackrel{\sigma}{g}}$ & $\begin{array}{l}\stackrel{0}{\sigma} \\
\stackrel{\leftrightarrow}{\rightarrow}\end{array}$ & $\begin{array}{l}m \\
\stackrel{\sigma}{\sigma} \\
\stackrel{\infty}{\infty}\end{array}$ \\
\hline 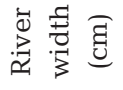 & $\stackrel{\circ}{\stackrel{\circ}{N}}$ & 웅 & $\begin{array}{l}\infty \\
0 \\
0\end{array}$ & ஓ \\
\hline$\stackrel{\text { E }}{n}$ & 5 & $\stackrel{*}{\mathrm{D}}$ & $\stackrel{*}{3}$ & $\stackrel{*}{*}$ \\
\hline
\end{tabular}
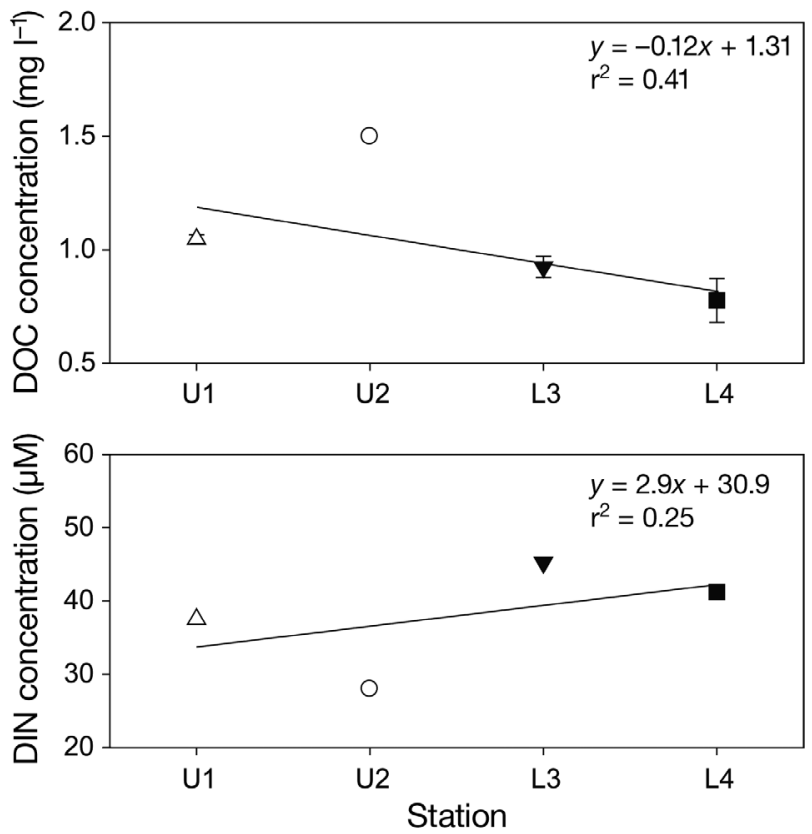

Fig. 3. Distribution of dissolved inorganic nitrogen (DIN) and dissolved organic carbon (DOC) concentrations at each station in the Inukami River (see Figs. 1 \& 2). Data are mean $\pm 1 \mathrm{SE}(\mathrm{n}=4)$ values; lines show regressions

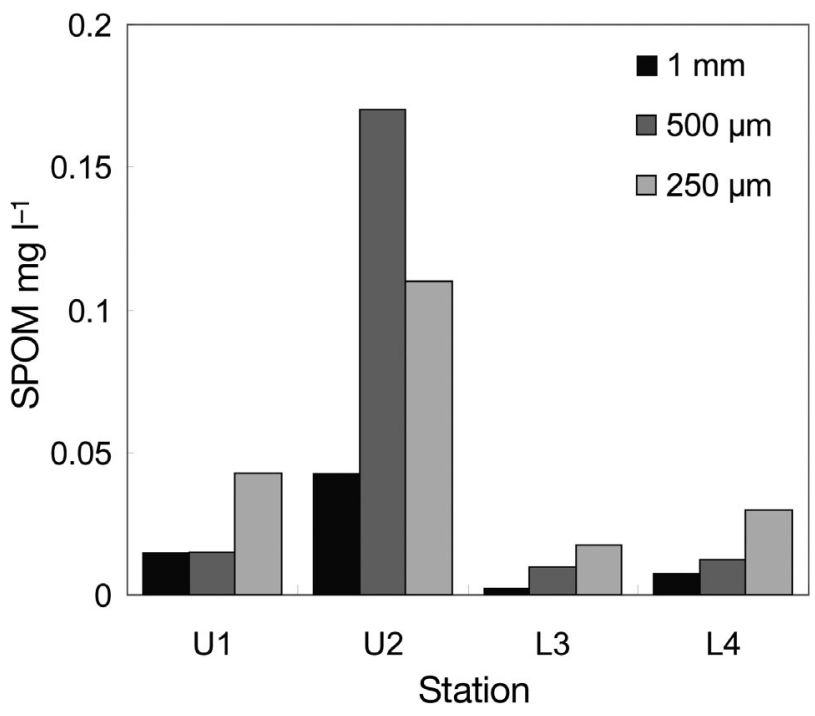

Fig. 4. Suspended particulate organic matter (SPOM) concentrations, of different size classes, at each station in the Inukami River (see Figs. 1 \& 2)

\section{Isotopic signatures of Stenopsyche marmorata and its basal resources}

Isotopic signatures and a dual stable isotope plot $\left(\delta^{13} \mathrm{C}\right.$ and $\delta^{15} \mathrm{~N}$ ) of the consumers (S. marmorata) and their food sources (SPOM, BPOM, and periphyton) are shown in Table 2 and Fig. 6. The $\delta^{13} \mathrm{C}$ and $\delta^{15} \mathrm{~N}$ values of $S$. mar- 
morata, SPOM, and BPOM were significantly different among U1, U2, and the lower reaches (L3 and L4).

SPOM $\delta^{13} \mathrm{C}$ values increased from U1 to U2 and subsequently decreased from U2 to the lower reaches, while $\delta^{15} \mathrm{~N}$ values increased gradually from $\mathrm{U} 1$ to the lower reaches. Similarly, BPOM $\delta^{13} \mathrm{C}$ values increased from U1 to U2 and decreased from U2 to the lower reaches, while $\delta^{15} \mathrm{~N}$ values increased from U1 to the lower reaches. Stenopsyche marmorata $\delta^{13} \mathrm{C}$ and $\delta^{15} \mathrm{~N}$ values followed a pattern similar to that of SPOM and BPOM. That is, $\delta^{13} \mathrm{C}$ values increased gradually from $\mathrm{U} 1$ to $\mathrm{U} 2$ (-21.6 to $-19.2 \%$ ) and decreased from U2 to the lower reaches (L3 and L4: -22.5 and $-22.7 \%$ ). The $\delta^{15} \mathrm{~N}$ values increased from U1 to U2 (2.0 to $3.9 \%$ ) and then increased again at the lower reaches (L3 and L4: both 6.2\%o). Periphyton $\delta^{13} \mathrm{C}$ and $\delta^{15} \mathrm{~N}$ values were significantly different among stations. In particular, U1 showed significantly higher $\delta^{13} \mathrm{C}(-14.8 \%)$ and lower $\delta^{15} \mathrm{~N}(0.3 \%)$ values compared to those at the other stations.

\section{Contribution of basal resources to Stenopsyche marmorata}

The contributions of basal resources to $S$. marmorata larvae showed high BPOM in both the upper (>60\%) and lower (>80\%) reaches according to the 3 -isotope mixing model (Table 3). Thus, to estimate the autochthonous contribution to BPOM $\delta^{13} \mathrm{C}$ values, we calculated the periphytic algal and terrestrial litter contributions to BPOM using the 2-isotope mixing model (Fig. 7). The periphytic algal contribution to BPOM changed little at L3 and L4 $(47.3 \pm 0.5$ and $59.0 \pm 1.9 \%$, respectively). In contrast, these values increased between U1 $(13.3 \pm 5.6 \%)$ and U2 $(79.3 \pm 12.5 \%)$. The periphytic algal contribution to BPOM differed among all stations $(\mathrm{p}<0.01)$.

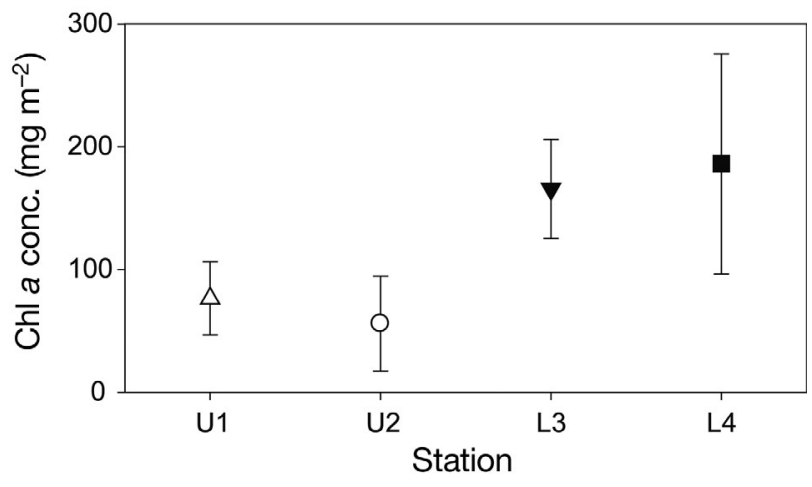

Fig. 5. Chlorophyll a (chl a) concentration at each station in the Inukami River (see Figs. $1 \& 2$ ). Data are mean \pm SD

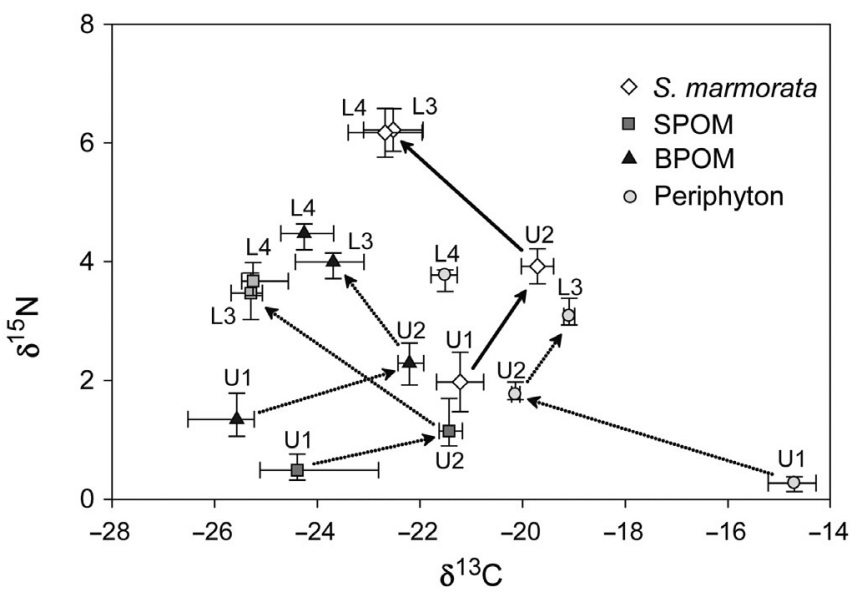

Fig. 6. Carbon and nitrogen stable isotope plots of Stenopsyche marmorata and its food sources (suspended particulate organic matter [SPOM], benthic particulate organic matter [BPOM], and periphyton) in the Inukami River (see Figs. $1 \& 2$ ). Data are mean $\pm \mathrm{SD}$

Table 2. $\delta^{13} \mathrm{C}$ and $\delta^{15} \mathrm{~N}$ values (mean [SD]) of Stenopsyche marmorata, suspended particulate organic matter (SPOM), benthic particulate organic matter (BPOM), and periphyton collected at each station (see Figs. 1 \& 2). Mean (SD) values marked by the same letter are not significantly different (Tukey multiple comparison, $\mathrm{p}>0.05$ ); unmarked mean (SD) values are significantly different (1-way ANOVA, p < 0.01). *data from Shin et al. (in press)

\begin{tabular}{|c|c|c|c|c|c|c|c|c|}
\hline \multirow{2}{*}{ Consumer/food source } & \multicolumn{4}{|c|}{ - Station } & \multirow[t]{2}{*}{$\mathrm{n}$} & \multirow{2}{*}{$\mathrm{df}$} & \multirow[t]{2}{*}{$F$} & \multirow[t]{2}{*}{$\mathrm{p}$} \\
\hline & U1 & U2 & L3 & L4 & & & & \\
\hline \multicolumn{9}{|l|}{$\delta^{13} \mathrm{C}(\%)$} \\
\hline S. marmorata & $-21.2(0.5)$ & $-19.7(0.3)$ & $-22.5(0.6)^{\mathrm{a}}$ & $-22.7(0.7)^{\mathrm{a}}$ & 46 & 3 & 88.4 & $<0.01$ \\
\hline SPOM & $-24.0(1.2)^{\mathrm{c}}$ & $-21.4^{*}(0.2)$ & $-25.4^{*}(0.3)^{b}$ & $-25.0^{*}(0.5)^{b, c}$ & 17 & 3 & 32.8 & $<0.01$ \\
\hline BPOM & $-25.9(0.7)$ & $-22.2^{*}(0.3)$ & $-23.8^{*}(0.7)^{\mathrm{d}}$ & $-24.3^{*}(0.4)^{\mathrm{d}}$ & 17 & 3 & 31.4 & $<0.01$ \\
\hline Periphyton & $-14.8(0.5)$ & $-20.1^{*}(0.1)$ & $-19.1^{*}(0.1)$ & $-21.6^{*}(0.2)$ & 17 & 3 & 491 & $<0.01$ \\
\hline \multicolumn{9}{|l|}{$\delta^{15} \mathrm{~N}(\%)$} \\
\hline S. marmorata & $2.0(0.5)$ & $3.9(0.3)$ & $6.2(0.4)^{\mathrm{e}}$ & $6.2(0.4)^{\mathrm{e}}$ & 46 & 3 & 209 & $<0.01$ \\
\hline SPOM & $0.5(0.2)$ & $1.3^{*}(0.4)$ & $3.4^{*}(0.4)^{f}$ & $3.7^{*}(0.3)^{\mathrm{f}}$ & 17 & 3 & 97.3 & $<0.01$ \\
\hline BPOM & $1.4(0.4)$ & $2.3^{*}(0.4)$ & $3.9^{*}(0.2)^{g}$ & $4.4^{*}(0.2)^{g}$ & 17 & 3 & 99.8 & $<0.01$ \\
\hline Periphyton & $0.3(0.1)$ & $1.8^{*}(0.2)$ & $3.2 *(0.2)$ & $3.7^{*}(0.2)$ & 17 & 3 & 329 & $<0.01$ \\
\hline
\end{tabular}


Table 3. Contribution of food sources (suspended particulate organic matter [SPOM], benthic particulate organic matter [BPOM], and periphyton) to the Stenopsyche marmorata diet at each station (see Figs. 1 \& 2) calculated using the IsoSource mixing model (Phillips \& Gregg 2003). Data are mean (SD)

\begin{tabular}{|lccc|}
\hline Station & SPOM $(\%)$ & BPOM $(\%)$ & Periphyton (\%) \\
\hline U1 & $1.4(1.3)$ & $64.6(0.1)$ & $34.0(0.1)$ \\
U2 & $1.2(1.2)$ & $63.4(1.7)$ & $35.5(2.2)$ \\
L3 & $6.6(5.0)$ & $88.8(4.5)$ & $4.6(3.6)$ \\
L4 & 0 & 100 & 0 \\
\hline
\end{tabular}

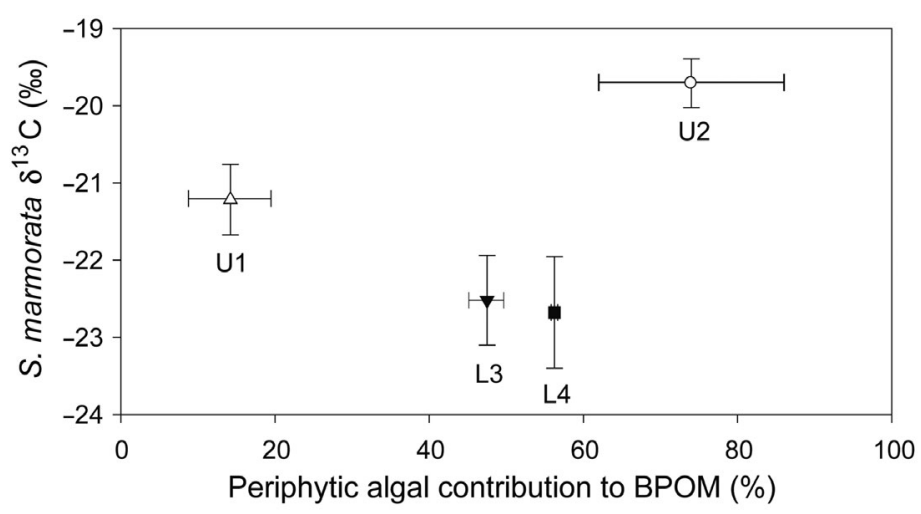

Fig. 7. Relationship between Stenopsyche marmorata $\delta^{13} \mathrm{C}$ values and the contribution of periphytic algae to benthic particulate organic matter (BPOM) at each station (see Figs. 1 \& 2), calculated

by the isotope mixing model. Data are mean $\pm 1 \mathrm{SE}(\mathrm{n}=4)$

\section{DISCUSSION}

\section{Physicochemical features in an intermittent river}

The vertical upwelling and lateral input of groundwater from a hillslope into the hyporheic zone of a river have been inferred from the concentrations of conservative solutes such as chlorides and silicates found in rivers (Mulholland \& Hill 1997, Hill et al. 1998, Pinay et al. 1998, Baker \& Vervier 2004). The major ions of sodium, chloride, sulfate, and bicarbonate were the most significant parameters in comparative analyses of base flow (Rose 2007) and groundwater resources (Vanderzalm et al. 2011). Our study suggests that water quality in the upper and lower reaches differs in chloride, sulfate, and sodium concentration and in $\mathrm{pH}$ (Table 1). In parts of rivers, such as in the lower reaches in the present study, where groundwater discharges from the underground layer to the river bottom or from the shallow subsurface riparian zone (Rose 2007), water quality is influenced by seepage water. Furthermore, relatively high concentrations of inorganic nitrogen and phosphorus in the lower reaches were probably caused by the inflow of seepage water via groundwater.

\section{Relationship between shifts in the trophic pathways of Stenopsyche marmorata and the dry channel}

The $\delta^{13} \mathrm{C}$ and $\delta^{15} \mathrm{~N}$ values of $S$. marmorata shifted in a pattern similar to that of basal resources from the upper to the lower reaches. This shift indicates that $S$. marmorata larvae assimilated basal resources in situ. The $\delta^{13} \mathrm{C}$ and $\delta^{15} \mathrm{~N}$ values of local organic matter are thought to show high variability (Maksymowska et al. 2000) and are linked to both primary producers and environmental features (Duarte \& Cebrian 1996), which suggests that $S$. marmorata $\delta^{13} \mathrm{C}$ and $\delta^{15} \mathrm{~N}$ values reflect not only the features of local food sources, but also the stepwise enrichment from primary producer to consumer.

In terms of basal resources, the results of our 3isotope mixing model showed that Stenopsyche marmorata might be feeding mainly on BPOM (Table 3), which may be important to energy flow, not only in a river associated with canopy cover (Doi et al. 2007), but also in an intermittent river. However, food source contributions to $S$. marmorata in the upper reaches consisted of both BPOM (>60\%) and periphyton (>30\%), whereas food source contributions in the lower reaches consisted mainly of BPOM (>80\%). These results suggest that food sources assimilated by $S$. marmorata were relatively different in the upper and lower reaches.

Based on the contributions of BPOM as a food source for consumers shown in the 2-isotope mixing model, Stenopsyche marmorata larvae at U1 may have been feeding on BPOM derived from terrestrial litter, indicating a greater reliance on allochthonous resources. At U2, L3, and L4, however, the larvae may have been feeding on BPOM originating from periphytic algal matter, indicating a greater reliance on autochthonous resources. This finding suggests that consumers in intermittent stream systems depend on various food sources, both allochthonous and autochthonous.

In sunlit portions of the subflow area, the significantly higher water temperature at U2 (subflow station) was probably due to the presence of stagnant water, which formed during the subflow process and was subject to concentrated solar heating during low current velocity, low water depth, and low discharge. Such water movement conditions may be conducive to the growth of algae, which might prefer the relatively high concentrations of easily absorbed ammonium; algae can occur in rich blooms in some standing waters (Allan 1995). Invertebrates (herbivores) collected at the pool edges, where there is less water exchange with the main channel, showed enriched $\delta^{13} \mathrm{C}$ values due to high water temperatures (Finlay et al. 1999). Thus, the enriched $\delta^{13} \mathrm{C}$ values of Stenopsyche marmorata may be due to assimilated high periphytic algal contents, suggesting increased photosynthetic activity 
in relation to $\mathrm{pH}$, because of significantly higher water temperatures and stagnant water.

Doi et al. (2007) reported that the $\delta^{13} \mathrm{C}$ values of filter feeders and BPOM are highly influenced by variations in in situ periphytic algal productivity. In the lower reaches, a relatively high algal biomass (measured as chl a concentration; Fig. 5), suggested that these values contributed to the high periphytic algal content of BPOM in this part of the river. Moreover, relatively low DOC (Fig. 3) and SPOM concentrations (Fig. 4) in the lower reaches may be explained by the lack of carbon input from ambient waters or the reduced supply of terrestrial DOC from the upper to the lower reaches because of the interruption of the river continuum caused by the dry channel. In the lower reaches, periphytic algae may be a significantly important food source for consumers based on their $\delta^{13} \mathrm{C}$ values, because the contributions of terrestrial food sources to consumers were reduced.

$\delta^{13} \mathrm{C}$ values of producers and consumers vary according to changes in pH (Finlay et al. 2002, Doi et al. 2006). In the present study, the relatively low $\delta^{13} \mathrm{C}$ values of Stenopsyche marmorata and its food sources in the lower reaches (Table 2) seem to be explained by low $\mathrm{pH}$. If the algae use bicarbonate as a carbon substrate, these $\delta^{13} \mathrm{C}$ values are enriched, because the $\delta^{13} \mathrm{C}$ value of the bicarbonate is isotopically heavier than that of $\mathrm{CO}_{2}$ and the isotope fractionation in carbonic anhydrase is negative (Yoshioka 1997). Moreover, the spring's source region possibly showed the diminished $\delta^{13} \mathrm{C}$ value, because the $\delta^{13} \mathrm{C}$ content of inorganic carbon at the spring was affected by the $\mathrm{CO}_{2}$ release of biogenic respiration in riverbed soil (Rounick \& James 1984), and primary producers at the spring use mainly $\mathrm{CO}_{2}$ gas from groundwater inflow (Finlay 2004). In the present study, photosynthetic activity of periphyton may have mainly used $\mathrm{CO}_{2}$ in groundwater because the lower reaches were influenced by seepage water derived from groundwater. Therefore, BPOM derived from periphytic algae showed more negative $\delta^{13} \mathrm{C}$ values, and $S$. marmorata $\delta^{13} \mathrm{C}$ values likely reflected low $\delta^{13} \mathrm{C}$ assimilation.

Our results showed enriched $\delta^{15} \mathrm{~N}$ values in Stenopsyche marmorata and its food sources (Table 2, Fig. 6) and relatively high DIN concentrations in the lower reaches. These findings are similar to those of McClelland \& Valiela (1998), who stated that the $\delta^{15} \mathrm{~N}$ values of the nitrate in groundwater were enriched as wastewater contributions to the nitrate pool in groundwater increased. Furthermore, high concentrations of chloride, sulfate, and sodium ions in the lower reaches suggest the influence of industrial activities, such as the inflow of contaminants from the surrounding watershed (Verbanck et al. 1989). Accordingly, in the lower reaches, a high DIN concentration in the groundwater may contribute to the enriched $\delta^{15} \mathrm{~N}$ values of food sources, and $S$. marmorata probably showed enriched $\delta^{15} \mathrm{~N}$ values because of feeding on these food sources (Table 2, Fig. 6).

Prior food web studies on the origin of food sources in intermittent river systems show conflicting results (Dekar et al. 2009); some studies report that the food web has allochthonous resource origins (Reid et al. 2008, Dekar et al. 2009), and others report autochthonous resource origins (Bunn et al. 2003). In terms of basal resources, our results likely show the relative importance of autochthonous resources to consumers. However, these conflicting results may be due to different local conditions, such as hydrology, climate, pool size, and landscape (Reid et al. 2008).

We did not investigate the effect of temporal variability on energy and nutrient flow in an intermittent river. However, our results illustrate the difference in trophic positions and trophic pathways based on physicochemical characteristics and the potential importance of autochthonous resources to the energy sources of consumers - the trichopteran filter feeder Stenopsyche marmorata — in an intermittent river.

Acknowledgements. We thank Prof. I. Tayasu and N. Ishikawa, from the Center for Ecological Research, Kyoto University, for their assistance with the stable isotope analytical facilities and their incisive suggestions. We also are indebted to T. Akatsuka, H. Azumi, L. Ao, and N. Amahashi from the Limnological Laboratory, University of Shiga Prefecture, for their generous assistance with the field work. The present study was conducted using the Cooperative Research Facilities (Isotope Ratio Mass Spectrometer) of the Center for Ecological Research, Kyoto University.

\section{LITERATURE CITED}

Allan JD (1995) Stream ecology: structure and function of running waters. Chapman and Hall, London

Arab A, Lek S, Lounaci A, Park YS (2004) Spatial and temporal patterns of benthic invertebrate communities in an intermittent river (North Africa). Ann Limnol 40:317-327

> Baker MA, Vervier P (2004) Hydrological variability, organic matter supply and denitrification in the Garonne River ecosystem. Freshw Biol 49:181-190

Bendschneider K, Robinson RJ (1952) A new spectrophotometric method for the determination of nitrite in sea water. J Mar Res 11:87-96

Bunn SE, Davies PM, Winning M (2003) Sources of organic carbon supporting the food web of an arid zone floodplain river. Freshw Biol 48:619-635

Caraco NF, Cole JJ (2004) Food webs at the landscape level. In: Polis GA, Power ME, Huxley GR (eds) University of Chicago Press, Chicago, p 301-316

Cole JJ, Caraco NF (2001) Carbon in catchments: connecting terrestrial carbon losses with aquatic metabolism. Mar Freshw Res 52:101-110

> Dekar MP, Magoulick DD, Huxel GR (2009) Shifts in the trophic base of intermittent stream food webs. Hydrobiologia 635:263-277 
DeNiro MJ, Epstein S (1978) Influence of diet on the distribution of carbon isotopes in animals. Geochim Cosmochim Acta 42:495-506

Doi H, Zuykova EI, Kikuchi E, Shikano S, Kanou K, Yurlova N, Yadrenkina E (2006) Spatial changes in carbon and nitrogen stable isotopes of the plankton food web in a saline lake ecosystem. Hydrobiologia 571:395-400

Doi H, Takemon Y, Ohta T, Ishida Y, Kikuchi E (2007) Effects of reach scale canopy cover on trophic pathways of caddisfly larvae in a Japanese mountain stream. Mar Freshw Res 58:811-817

Duarte CM, Cebrian J (1996) The fate of marine autotrophic production. Limnol Oceanogr 41:1758-1766

Finlay JC (2001) Stable-carbon-isotope ratios of river biota: implications for energy flow in lotic food webs. Ecology 82: 1052-1064

Finlay JC (2004) Patterns and controls of lotic algal stable carbon isotope ratios. Limnol Oceanogr 49:850-861

Finlay JC, Power ME, Cabana G (1999) Effects of water velocity on algal carbon isotope ratios: implications for river food web studies. Limnol Oceanogr 44:1198-1203

Finlay JC, Khandwala S, Power ME (2002) Spatial scales of carbon flow in a river food web. Ecology 83:1845-1859

Focken U, Becker K (1998) Metabolic fractionation of stable carbon isotopes: implications of different proximate compositions for studies of the aquatic food webs using $\delta^{13} \mathrm{C}$ data. Oecologia 115:337-343

Folch J, Lees M, Sloane-Stanley GH (1957) A simple method for the isolation and purification of total lipids from animal tissues. J Biol Chem 226:497-509

France RL (1995) Critical examination of stable isotope analysis as a means for tracing carbon pathways in stream ecosystems. Can J Fish Aquat Sci 52:651-656

- Hill AR, Labadia CF, Sanmugadas K (1998) Hyporheic zone hydrology and nitrogen dynamics in relation to the streambed topography of a N-rich stream. Biogeochemistry 42:285-310

Hungate BA, Marks JC (2002) Impacts of global change on terrestrial and aquatic ecosystems. In: Canadell J, Mooney HA (eds) Encyclopedia of global change, Vol 2. The Earth system: biological and ecological dimensions of global environmental change. John Wiley and Sons, New York, NY, p 122-134

Iwadate $\mathrm{T}$, Hodoki Y, Ohbayashi K, Murakami T, Ono Y (2007) Predominance of Stenopsyche marmorata Navas larvae immediately downstream of Iwaonai Dam in the Teshio River, Hokkaido, Japan. Jap J Limnol 68:41-49 (Japanese)

Maksymowska D, Richard P, Piekarek-Jankowska H, Riera P (2000) Chemical and isotopic composition of the organic matter sources in the Gulf of Gdansk (southern Baltic Sea). Estuar Coast Shelf Sci 51:585-598

McClelland JW, Valiela I (1998) Linking nitrogen in estuarine producers to land-derived sources. Limnol Oceanogr 43: $577-585$

Minagawa M, Wada E (1984) Stepwise enrichment of ${ }^{15} \mathrm{~N}$ along food chains: further evidence and the relation between $\delta^{15} \mathrm{~N}$ and animal age. Geochim Cosmochim Acta 48: 1135-1140

Mulholland PJ, Hill WR (1997) Seasonal patterns in streamwater nutrient and dissolved organic carbon concentrations: separating catchment flow path and in-stream effects. Water Resour Res 33:1297-1306

Mullin JB, Riley JP (1955) The colorimetric determination of silicate with special reference to sea and natural waters. Anal Chim Acta 12:162-176
Murphy J, Riley JP (1962) A modified single solution method for the determination of phosphate in natural waters. Anal Chim Acta 27:31-36

Phillips DL, Gregg JW (2001) Uncertainty in source partitioning using stable isotopes. Oecologia 127:171-179

Phillips DL, Gregg JW (2003) Source partitioning using stable isotopes: coping with too many sources. Oecologia 136: 261-269

Pinay G, Ruffinoni C, Wondzell S, Gazelle F (1998) Change in groundwater nitrate concentration in a large river floodplain: Denitrification, uptake, or mixing? J N Am Benthol Soc 17:179-189

> Post DM (2002) Using stable isotopes to estimate trophic position: models, methods, and assumptions. Ecology 83: 703-718

> Rains MC, Fogg GE, Harter T, Dahlgren RA, Williamson RJ (2006) The role of perched aquifers in hydrological connectivity and biogeochemical processes in vernal pool landscapes, Central Valley, California. Hydrol Process 20: 1157-1175

> Reid DJ, Quinn GP, Lake PS, Reich P (2008) Terrestrial detritus supports the food webs in lowland intermittent streams of south-eastern Australia: a stable isotope study. Freshw Biol 53:2036-2050

Rose S (2007) The effects of urbanization on the hydrochemistry of base flow within the Chattahoochee River Basin (Georgia, USA). J Hydrol 341:42-54

Rounick JS, James MR (1984) Geothermal and cold springs faunas: inorganic carbon sources affect isotope values. Limnol Oceanogr 29:386-389

Rounick JS, Winterbourn MJ, Lyon GL (1982) Differential utilization of allochthonous and autochthonous inputs by aquatic invertebrates in some New Zealand streams: a stable carbon isotope study. Oikos 39:191-198

Sagi T (1966) Determination of ammonia in sea water by the indophenol method and its application to the coastal and off-shore waters. Oceanogr Mag 18:43-51

Shin HS, Amahashi N, Ao L, Mitamura O (in press) Variation in trophic pathways and food web characteristics revealed by stable isotopes in an intermittent stream system of the Inukami River, Japan. Anim Cell Sys

Thorp JH, Delong MD (2002) Dominance of autochthonous autotrophic carbon in food webs of heterotrophic rivers. Oikos 96:543-550

> Vanderzalm JL, Jeuken BM, Wischusen JDH, Pavelic P, Le Gal La Salle C, Knapton A, Dillon PJ (2011) Recharge sources and hydrogeochemical evolution of groundwater in alluvial basins in arid central Australia. J Hydrol 397: 71-82

- Vannote RL, Minshall GW, Cummins KW, Sedell JR, Cushing CE (1980) The river continuum concept. Can J Fish Aquat Sci 37:130-137

Verbanck M, Vanderborght JP, Wollast R (1989) Major ion content of urban wastewater: assessment of per capita loading. J Water Pollut Control Fed 61:1722-1728

Wigington PJ Jr, Ebersole JL, Colvin ME, Leibowitz SG and others (2006) Coho salmon dependence on intermittent streams. Front Ecol Environ 4:513-518

> Williams DD (1996) Environmental constraints in temporary fresh waters and their consequences for the insect fauna. J N Am Benthol Soc 15:634-650

> Winkler LW (1888) The determination of dissolved oxygen in water. Berlin Deut Chem Ges 21:2843-2855

> Yoshioka T (1997) Phytoplanktonic carbon isotope fractionation: equations accounting for $\mathrm{CO}_{2}$-concentrating mechanisms. J Plankton Res 19:1455-1476

Submitted: August 2, 2010; Accepted: April 6, 2011

Proofs received from author(s): June 4, 2011 